\title{
Parent Participation in the Spanish School System: School Councils
}

\author{
Verónica Cobano-Delgado ${ }^{1}$ \\ ${ }^{1}$ Facultad de Ciencias de la Educación, Universidad de Sevilla, Sevilla, Spain \\ Correspondence: Departamento de Teoría e Historia de la Educación y Pedagogía Social, C/Pirotecnia s/n, \\ Sevilla, 41013, Spain. Tel: 349-5542-0575. E-mail: cobano@us.es
}

Received: May 11, $2015 \quad$ Accepted: June 13, $2015 \quad$ Online Published: October 28, 2015
$\begin{aligned} & \text { doi:10.5539/ies.v8n11p156 } \\ & \text { URL: http://dx.doi.org/10.5539/ies.v8n11p156 }\end{aligned}$

\begin{abstract}
Parents of pupils participate in the supervision and management of Spanish schools through the School Council [Consejo Escolar], which is the principal body through which such participation and oversight is channeled. Through it families, pupils, teachers and non-teaching staff contribute collectively to making the important decisions affecting schools. Its members are chosen by means of an electoral process that must be public and objective; voting must be personal, direct, secret and not delegable. The Council's composition varies from one Autonomous Community to another and its character depends on the characteristics of each school - public or private - on the type of education offered as well as on the space, teaching staff and pupils it has at its disposal. Under the recent educational reform, democratic participation on the part of the various sectors which make up the school community has been drastically curtailed. Parents' representatives, teachers, pupils, administrative and municpal staff on the School Council find their contribution relegated to a merely consultative level.
\end{abstract}

Keywords: school councils, parents, school, Spain

\section{Introduction}

The current Spanish education system is the outcome of a series of social and political events whose origins can be traced to the beginning of the nineteenth century. Since then there have been many changes in the field of education, and the pendulum has swung constantly between liberal and conservative perspectives.

In 1809, Jovellanos presented to the Supreme Central Junta the Bases for the Formulation of the General Plan of Public Instruction [Bases para la Formación de un Plan General de Instrucción Pública], which served as a reference point for subsequent liberal administrations; in it he called for education free of charge for all citizens. Three years later, the Constitution of 1812 was adopted, the Title IX of which called for schools to be set up in all towns of the monarchy for the teaching of reading and writing, arithmetic, and the catechism. Children should also have explained to them the rights and duties of the citizen. In the Regency period, Manuel José Quintana presented to the Cortes an Opinion and Draft Decree on the General Reform of Public Education [Dictamen $y$ Proyecto de Decreto sobre el Arreglo General de la Enseñanza Pública] (1814), in which equality was sought for all Spanish citizens in terms of type of education, and methods and language employed; at the same time it called for the existence of State-supported public education, parallel to private education.

With the restoration of Ferdinand VII came the publication of the Decree of May 4, 1814 by which measures taken in the earlier period were repealed and education left largely in the hands of the Church. Liberal principles in the field of education were reaffirmed in the Royal Decree of August 4, 1836, which exerted a considerable influence on the Pidal Plan of 1845 and the Moyano Law of 1857 (Pozo, 2005). This latter law embodied the traditional "moderantismo" in education: among its salient characteristics were limited freedom of education, secularisation, primary education largely free of charge, and a centralised administration. In addition, compulsory education was established for children between the ages of six and nine, with fines to be imposed on parents who failed to comply.

Freedom of education was enshrined in the Decree of October 21, 1868. The Constitution of 1931 stated that primary education should be compulsory and free of charge and established the principle of a single and secular school system. In 1970 the General Law regulating Education and the Financing of Educational Reform was passed (BOE, 1970), which opened up new horizons and constituted a novel way of regulating the structures of the education system that had been in place since the time of the Moyano Law. Thus a compulsory, free and unified elementary education system was legislated for in Spain, one conceived as a public service for which the 
State was responsible. However, although a number of its articles are still in force, the law was a failure as it had not been fully implemented on account of a lack of political will on the part of successive governments.

In December 1978, the present Spanish Constitution was passed, Articles 16, 20, 27 and 44 of which address the field of education. After acknowledging the right to education and academic freedom (Art. 27.1), the Constitution states that the essential aim of education is nothing other than the full development of the human personality with due respect for the democratic principles of coexistence (Art. 27.2). It reaffirms furthermore that elementary education should be compulsory and free of charge (Art. 27, 4), and encourages the effective participation of the sectors concerned in all matters relating to general education programming (Art. 27.5 and 27.7).

The public authorities guarantee the right of all citizens to education, by means of a general study plan in which all the sectors concerned participate. Equally, the right of individuals and legal entities to set up educational centres is recognised provided they respect constitutional principles (Art. 27, 6). The autonomy of Universities is also recognised under the terms established by law (Art. 27, 10).

The Schools Statute [Estatuto de Centros Escolares] (LOECE, 1980) partially develops Article 27 of the Constitution, specifically sub-sections 3-9 but without addressing the financing of private education at compulsory levels. The Constitutional Court would judge unconstitutional a number of these sub-sections. It is clearly stated that it falls within the scope of the public authorities to safeguard the social, economic and legal protection of the family (Art. 39, 1), and to guarantee the full protection of children, regardless of their parentage and the marital status of the mother. The law also provides for the possibility of investigating a child's paternity (Art. 39, 2). Parents must provide their children, whether born within or outside wedlock, with assistance of every kind while they are still under age and in other circumstances established by law (Art. 39, 3). By way of coda and drawing loose threads together, it is stated that children shall enjoy the protection provided for in the international agreements safeguarding their rights (Art. 39, 4).

In the Spanish Civil Code (1889) we can observe that parents have a series of obligations which are in harmony with the present Constitution, albeit in the language of the period in which it was devised. We refer to the following Articles:

1) Support shall also comprise education and instruction of the recipient of support while he is underage and even thereafter, when he has not finished his training for a cause not attributable to him (Art. 142).

2) Spouses are obliged to provide support to each other and to their descendants and ascendants in the nearest degree (Art. 143).

3) Non-emancipated children shall be under the parents' parental authority. Parents must look after them, have them in their company, feed them, educate them and seek to provide for them a comprehensive upbringing (Art. 154).

As far as the question of regional autonomy is concerned, it must be borne in mind that despite the existence prior to 1901 of various flashes of pro-independence activity, it was the general elections of that year, when the Regionalist League [Lliga Regionalista] won a clear victory in Barcelona, which signaled the emergence of regionalism in Spanish politics. In Spain's 1978 Constitution the ill-defined status of the regions during the period is patent. Thus article 2 states that Spain is a nation characterised by its indissoluble unity and that it is the common and indivisible homeland for all Spanish people yet at the same time it acknowledges and guarantees the right to autonomy of the nationalities and regions comprising it. The territorial organisation of the country and the powers and responsibilities of the municipal councils, provinces, Autonomous Communities and the State are likewise regulated in the Constitution (Spanish Constitution, 1978, Title VIII). There are some historians, however, among them Solé Tura, who believe that in spite of the important advance this represented on the previous period, the problem of the Autonomous Communities remains as yet unresolved (Proceedings of the Seminar in Commemoration of February 28, 1985).

The Spanish Constitution establishes a system of distribution of powers and responsibilities within the legal framework governing schools, which allows the Autonomous Communities to legislate on education (Spanish Constitution, 1978: Arts. 148 and 149). When in July 1985, the Organic Law 8/1985 regulating the right to education (LODE) came into force, those Autonomous Communities with transferred powers in education began to create their own regulations in the field.

The situation faced by the State government is an ever more awkward one given that the degree of decentralisation achieved by some of the Autonomous Communities has exceeded all expectations and triggered a surge in demands for equal treatment on the part of the rest. 
It should be emphasised that the Constitution leaves open to future legislation two aspects of undoubted importance: the teaching of regional languages and the decentralisation of educational administration. Both aspects depend on the extent to which each Autonomous Community has suceeded in having powers and responsibilities devolved.

The provision of education services corresponds primarily to the State and the Autonomous Communities. The former, by means of the general programme, determines the principal educational needs to be addressed. It then formulates objectives and assesses the resources required. The Autonomous Communities that have transferred competences are responsible for specific programming in schools, the promotion of culture and research, the teaching of regional languages and the regulation and administration of education in all its modalities, levels and stages. For their part, the municipal councils cooperate with the education Authorities in setting up, constructing and maintaining schools, as well as in the enforcement of compulsory schooling.

With the aim of ensuring coordination in educational policy and the exchange of information among the Autonomous Communities, the Conference of Education Ministers of the Autonomous Communities' Councils of Government was set up. Each Autonomous Region has a regional Ministry of Education [Consejería de Educación] with its corresponding Minister. Provincial Inspections are now integrated into the regional Administrations.

In summary, Spain can be said to undergoing a period of transition between an education system based on a strongly centralised tradition - a faithful reflection of the Napoleonic model - and a system in which the regional governments, through a series of ambitious Statutes of Autonomy, wield considerable power. As García (1984: 552) remarks, "The Spanish school system at present finds itself in the process of moving from a heavily centralised administrative structure and another which is openly decentralised, almost regionalist".

This system is currently immersed in a maelstrom of change that has affected legislation regulating education in recent years. The changes correlate with the political colouring of the whichever government is in power. As the Popular Party currently enjoys an absolute majority, we have witnessed the adoption and implementation of the Organic Law 8/2013, of December 9, 2013 (passed on November 28), on the Improvement of the Quality of Education [Ley Orgánica para la Mejora de la Calidad Educativa] (LOMCE), although this law might be better regarded as a modification of various articles of the previous law on education, the Organic Law on Education (LOE) of May 3, 2006.

It was not envisaged that the process of educational decentralisation would stop at the level of the Autonomous Communities but rather involve a gradual delegation of functions to lower levels, such as municipal councils, district councils and even the schools themselves. The reality, however, has been rather different. The majority of Autonomous Communities have not carried out extensive decentralisation. Indeed, their structures are practically the mirror-image of the centralist State model.

\section{School Councils}

The General Law on Education of 1970 contemplated the participation and representation of parents in schools through the Advisory Council [Consejo Asesor], that is to say, a Council with a right to express an opinion but not to vote.

In 1980, with the Organic Law regulating the Right to Education [Ley Orgánica Reguladora del Derecho a la Educación] (LOECE, 1980) a first attempt was made to involve parents in the way envisaged by the 1978 Constitution. This law regulated school statutes and Parents' Associations [Asociaciones de Padres de Alumnos] (APAS). Every school was to have a Parents' Association to which all parents or guardians of matriculated pupils could belong. Through it they could participate in the school's corporate bodies and carry out the following functions (Art. 18.1):

a) Defend parents' rights in matters affecting their children's education.

b) Elect their representatives and actively participate in the school's corporate bodies.

c) Collaborate in the work undertaken by schools, especially regarding extra-curricular activities.

d) Guide and stimulate parents to assume their duties in respect of their children's education.

e) Draw up, develop or modify, in collaboration with the teaching staff, the schools's internal regulations.

Along the same lines, the LOECE created the School Council, a body in which all sectors of the educational community would be represented - the school (Head Teacher [Director], Head of Studies, teachers and secretary), the municipal council, parents (through the AMPA [Parents' Association, formerly designated APAS]), pupils and administrative and service staff. 
Subsequently, the LOE stated that "participation is central to the formation of citizens who are autonomous, free, responsible, and committed to the principle values of the Constitution" and for this reason it assigned to the School Council a wide range of powers and responsibilities (Art. 127).

Thus the School Council was the principal body which participated in the management and supervision of schools, that is to say, the principal channel through which families, pupils, teachers and non-teaching staff were able to take part in making important decisions affecting the school. Members are chosen by means of an electoral process which must be public and objective. Voting must be personal, direct, secret and not delegable. The composition of the School Council varies according to the Autonomous Community and its character depends on the school, whether public or private, the subjects offered - primary, secondary, vocational, education for special needs, plastic arts and design, music, dance, drama, languages - as well as the space, teaching staff and pupils the school has at its disposal. Nevertheless, generally speaking, School Councils will be composed of the following members:

- The Head of the school, who will be the Chairperson.

- The Head of Studies.

- A representative of the municipal council.

- A number of teachers, elected by the Teachers' Council [Equipo de Profesores], which must not be less than a third of the total number of Teachers' Council members.

- A number of parents and students, elected respectively by and among themselves, which must not be less than a third of the total number of School Council members.

- A representative of the school's administrative and services staff.

- The school secretary, who will act as the secretary of the Council, with no voting rights.

The Statutes of the Autonomous Communities require that the constitutional provisions guaranteeing the involvement of members of the educational community in the supervision and management of schools be observed. To this end, they develop LODE Article 34, which guarantees the appropriate representation of the sectors concerned in the territory of each Autonomous Community.

Currently, with the entry into force of the Organic Law on the Improvement of Education (LOMCE), of December 10, 2013, there has been a considerable modification to Sections a), b), e), and i) of the Article 127 of the LOE (2006), on the powers and responsibilities of the School Council, the highest body of representation and participation in the school community. These are now reformulated as follows:

a) Assess the projects and standards referred to in Chapter II of Title V of the present Organic Law (those referring to school autonomy)

b) Assess the Annual General Programme of the school, without detriment to the authority of the Teachers' Council, in relation to teaching planning and organisation.

e) Report on student admissions subject to the regulations of this Law and corresponding provisions

i) Report on the guidelines for collaboration, with the local council and with other schools, entities and organisations, for educational and cultural purposes.

As can be seen, the School Council has been subjected to a drastic reduction of its scope of action. Where previously representatives of the educational community could 'approve', 'decide', 'propose', and 'lay down guidelines', now it can only 'assess' and 'report on' different matters relating to the pupils' education and school organisation and management.

The only function of a binding character that the LOMCE reserves for the School Council is approval of the school budget. The education project becomes the sole responsibility of the Head Teacher and parents will not be able, in the way they have done hitherto, to influence the broad guidelines of the school or put forward a possible motion of censure.

In addition, there is a diminution of the rights and duties of parents of pupils, as well as of the rest of the educational community, concerning the supervision and management of schools supported by public funds, as guaranteed by the Constitution. Perhaps for this reason, in April 2014, the Constitutional Court in plenary session admitted an appeal to have the law overturned on grounds of unconstitutionality (no. 1406-2014), given the way in which this and other polemical Articles have been formulated.

Starting from the present academic year 2014-2015, the implementation of the LOMCE will mark a radical 
departure from the spirit that inspired an educational system based on the participation of all interested parties. School Councils have become merely consultative bodies, with little decision-making powers, as these have passed to School Heads and their teams. There is thus a loss of independence in the running of schools and the democratic spirit of the school as an institution in which everyone is involved is likewise compromised. In the School Councils of publicly funded private schools, a member with full rights, such as the municipal representative, even disappears altogether.

In order for a law to survive on the statute book, a wide social and political consensus is required, one which will confer stability on the education system. The LOMCE repeats the mistakes of the past. Passed exclusively with the votes of the party in government and in the face of widespread rejection, it has been the object of seven appeals on grounds of unconstitutionality and given rise to a commitment from opposition parties to have it repealed.

\section{Conclusions}

In conclusion, democratic participation of the various sectors that comprise the school community has been severely curtailed. The role of parents' representatives, teachers, pupils, administrative staff and municipal representatives in the school councils has been relegated to a purely consultative one (LOMCE: Art. 80). Ostensibly for the sake of higher quality and excellence in education, the decision-making capacity of what had hitherto been the highest participatory body in schools, the School Council, has been reduced to a minimum (LOMCE: Art. 72). Although this body continues to be the guarantor of the educational community's participation in the supervision and management of the school's affairs, its role has been converted into a consultative one in order to increase the autonomy and powers of Head Teachers (LOMCE: Arts. 77 and 81), who thus acquire a primordial role. The result is that citizens find it more difficult to exercise their rights and obligations in the community, a key condition for the promotion of collective values through education and participation (Thezá, 2011).

Opinions opposed to the LOMCE are numerous and widespread, from the Autonomous Governments of Andalusia, Asturias, the Canary Islands, Catalonia and the Basque Country, which have adopted a clearly critical stance (Sanmartín, 2014), to a wide range of commentators and experts (Montaner, 2014; Prats, 2013; Europa Press, 2012).

In the face of this critical onslaught against the draft LOMCE and the law itself, few have spoken up in support; well-argued reflections from supporters of this reform are conspicuous by their absence (García, 2012; Aguirre, 2013; Europa Press, 2014).

\section{References}

Actas del seminario en conmemoración del 28 de febrero. (1985). Nacionalismo y Regionalismo en España. Córdoba, Servicio de Publicaciones de la Diputación Provincial de Córdoba.

Aguirre, A. M. (2013). "La LOMCE: aspectos de mejora en la dirección, en nuestra Ley actual”, en Educaweb. Retrieved from http://www.educaweb.com/noticia/2013/01/28/lomce-aspectos-mejora-direccion-nuestra-ley -actual-5960/

BOE. (1970). Ley 14/1970, de 4 de agosto, General de Educación y Financiamiento de la Reforma Educativa (LGE). Boletín Oficial del Estado 187: 12525-12546. Impreso.

Código Civil. (1982). Real Decreto de 24 de julio de 1889. Madrid, Boletín Oficial del Estado.

Constitución de la República Española. (1931). Cortes Constituyentes, 9 de diciembre de 1931. Madrid. Retrieved from http://www.congreso.es/docu/constituciones/1931/1931_cd.pdf

Constitucion Española. (1978). Constitución Española. Aprobada por las Cortes el 31 de octubre de 1978. Madrid, Boletín Oficial del Estado, December 29, 1978.

Constitución Política de la Monarquía Española. (1812). Promulgada en 1812, aprobada el 19 de marso de 1812. Imprenta Real. Cádiz. Retrieved from http://www.congreso.es/docu/constituciones/1812/P-0004-00002.pdf

Europa Press. (2012). "El exministro de Educación Federico Mayor Zaragoza impulsa la plataforma «Stop Ley Wert»”, en Sociedad, Abc.es. Retrieved from http://www.abc.es/sociedad/20121218/abci-plataformastopleywert-mayor-zaragoza-201212181651.html

Europa Press. (2014). "Trinidad Nogales defiende la "transición" de la LOE a la LOMCE”, en Expansión.com. Retrieved from http://www.expansion.com/2014/01/30/extremadura/1391094670.html?a=8c4d7487670d7fd $85 \mathrm{da} 61231 \mathrm{e} 014346 \mathrm{~b} \& \mathrm{t}=1392563029$ 
García, J. L. (2012). "Un prudente viraje”, en Educación, larazon.es. Retrieved from http://www.larazon.es/detalle_hemeroteca/noticias/LA_RAZON_489296/4359-un-prudente-viraje-por-joseluis-garcia-garrido\#.Uv-7qP1509E

LODE. (1985). Ley orgánica 8/1985, de 3 de julio, reguladora del Derecho a la Educación. Madrid, Boletín Oficial del Estado, June 4, 1985.

LOE. (2006). Ley Orgánica de Educación (LOE). 3rd May 2006. Jueves 4 mayo 2006, BOE núm. 106.

LOECE. (1980). Ley Orgánica 5/80, de 19 de junio, sobre Estatuto de Centros Escolares. Boletín Oficial del Estado N1 154, 27th June 1980.

LOMCE. (2013). Ley Orgánica 8/2013, de 9 de diciembre, para la mejora de la calidad educativa. Aprobada el 28 de noviembre. Publicada el 10 de diciembre de 2013. Madrid.

Montaner, J. M. (2014). “La involución de la enseñanza”, en Opinión, el país.es. Retrieved from http://ccaa.elpais.com/ccaa/2014/01/15/catalunya/1389813458_185765.html

Pozo, R. A. (2005). "La Ley de Bases de 17 de julio de 1857, autorizando al Gobierno para formar y promulgar una ley de Instrucción Pública", en Alma mater hispalense. Retrieved from $\mathrm{http}: / /$ personal.us.es/alporu/historia/ley_moyano.htm\#leybases

Prats, E. (2013). "Los cambios que propone la reforma Wert nos vuelven a situar de espaldas a Europa”, en Noticias, Universitat de Barcelona. Retrieved from http://www.ub.edu/web/ub/es/menu_eines/noticies/2013/08/009.html

Sanmartín, O. (2014). “Andalucía, País Vasco, Asturias, Cataluña y Canarias se resistirán a aplicar la Lomce”, en Educación, elmundoes. Retrieved from http://www.elmundo.es/espana/2014/01/29/52e8fab122601d695c8b4572.html

Thezá, M. A. (2011). "Los claro-oscuros de la ciudadanía en los estudios sobre participación: Algunas aproximaciones teóricas Manríquez", en Revista del CLAD Reforma y Democracia, n. 51, October, pp. $1-14$.

\section{Copyrights}

Copyright for this article is retained by the author(s), with first publication rights granted to the journal.

This is an open-access article distributed under the terms and conditions of the Creative Commons Attribution license (http://creativecommons.org/licenses/by/3.0/). 